\title{
An Archaeological Assessment of the Alazan Acequia (41BX620) in the Five Points Area of San Antonio, Bexar County, Texas
}

David L. Nickels

I. Waynne Cox

Center for Archaeological Research

Follow this and additional works at: https://scholarworks.sfasu.edu/ita

Part of the American Material Culture Commons, Archaeological Anthropology Commons, Environmental Studies Commons, Other American Studies Commons, Other Arts and Humanities Commons, Other History of Art, Architecture, and Archaeology Commons, and the United States History Commons

Tell us how this article helped you.

This Article is brought to you for free and open access by the Center for Regional Heritage Research at SFA ScholarWorks. It has been accepted for inclusion in Index of Texas Archaeology: Open Access Gray Literature from the Lone Star State by an authorized editor of SFA ScholarWorks. For more information, please contact cdsscholarworks@sfasu.edu. 
An Archaeological Assessment of the Alazan Acequia (41BX620) in the Five Points Area of San Antonio, Bexar County, Texas

\section{Creative Commons License}

\section{(c) (1) \&}

This work is licensed under a Creative Commons Attribution-NonCommercial 4.0 International License 


\section{An Archaeological Assessment of the Alazán Acequia (41BX620) in the Five Points Area of San Antonio, Bexar County, Texas}

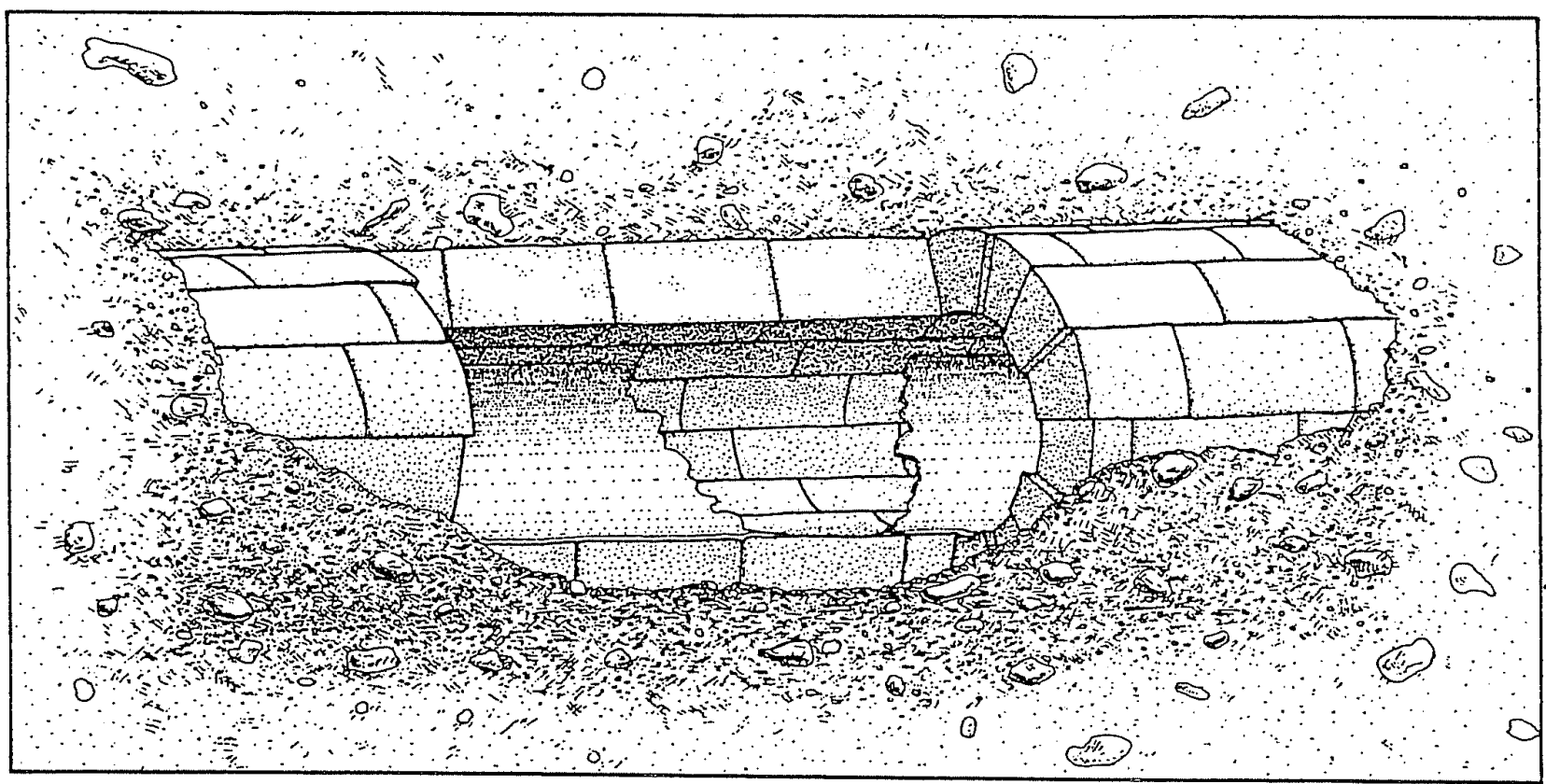

\section{David L. Nickels I. Waynne Cox}

Center for Archaeological Research The University of Texas at San Antonio Archaeological Survey Report, No. 253 



\title{
An Archaeological Assessment of the Alazán Acequia (41BX620) in the Five Points Area of San Antonio, Bexar County, Texas
}

\author{
David L. Nickels \\ I. Waynne Cox
}

Robert J. Hard and C. Britt Bousman

Principal Investigators

\author{
Ocopyright
}

Center for Archaeological Research The University of Texas at San Antonio Archaeological Survey Report, No. 253 
The following information is provided in accordance with the General Rules of Practice and Chapter 41.11 (Investigative Reports), Texas Antiquities Committee:

1. Type of investigation: Archival research, monitoring, and documentation

2. Project name: Alazán Acequia Assessment

3. County: Bexar

4. Principal Investigator: Robert J. Hard; co-principal investigator: C. Britt Bousman

5. Name and location of sponsoring agency: San Antonio River Authority, P.O. Box 830027, San Antonio, Texas 78283-0027

6. Texas Antiquities Committee Permit No.: n/a

7. Published by the Center for Archaeological Research, The University of Texas at San Antonio, 782490658, 1996

A list of publications offered by the Center for Archaeological Research is available. Call (210) 458-4378; write to the Center for Archaeological Research, The University of Texas at San Antonio, 6900 N. Loop 1604 W., San Antonio, Texas 78249-0658; e-mail to car@lonestar.utsa.edu; or visit CAR's web site at http://www.csbs.utsa.edu/research/car/index.htm. 


\begin{abstract}
In May 1996, while tunneling for a sewer line at the intersection of Cornell Street and Fredericksburg Road north of downtown San Antonio, contractors with the San Antonio River Authority (SARA) encountered the late-nineteenth-century Alazán Acequia from 7-14 ft below the modern surface. The Center for Archaeological Research entered into a contract with SARA to document the architecture and location of the acequia. The 1876 irrigation ditch, designated site 41BX620, was documented by photographs and measured drawings. A plan map of the location was drawn, and an artist's conception of the architecture involved was produced from photographs, drawings, and archaeologists' descriptions.
\end{abstract}




\section{Contents}

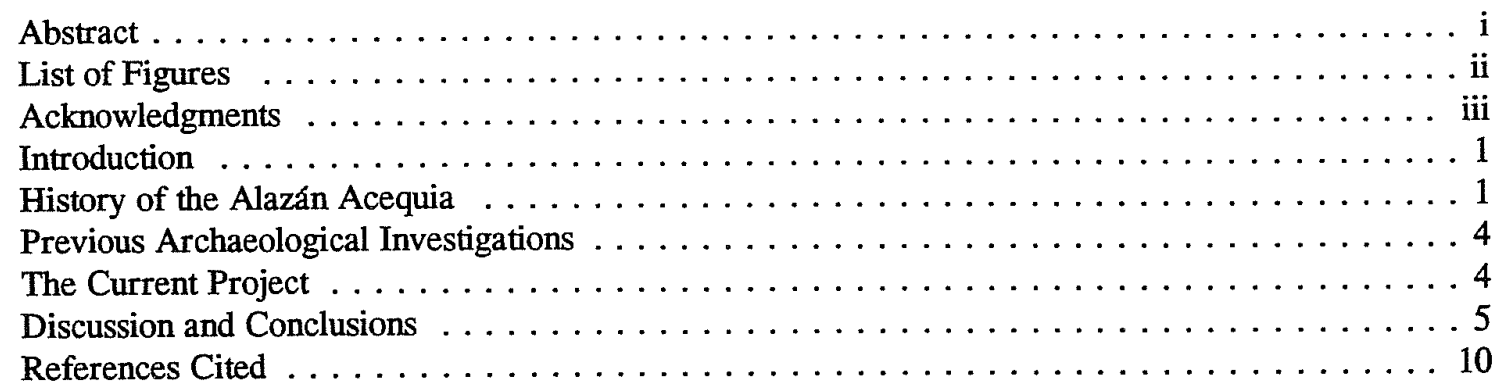

\section{Figures}

1. Route of the Alazán Acequia and areas of archaeological investigations. . . . . . . . . 3

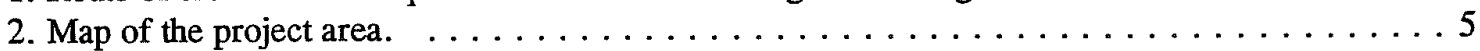

3. SARA construction crews encountered the Alazán Acequia from the east side. . . . . . . 6

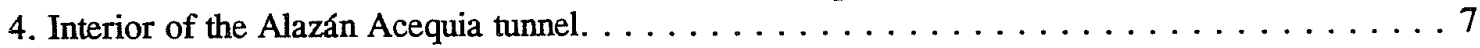

5. Artist's conception of the Alazán Acequia tunnel architecture. $\ldots \ldots \ldots \ldots \ldots \ldots \ldots$

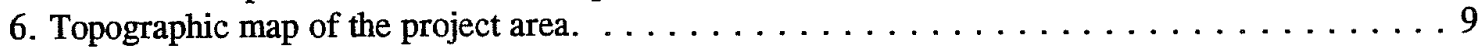




\section{Acknowledgments}

Mr. F. D. (Dean) Bayer, engineer with the San Antonio River Authority (SARA), was extremely helpful and cooperative in providing CAR with maps and information regarding construction plans and schedules. William (Joe) Shannon, engineering technician of SARA, provided CAD mapping and information that proved invaluable to determine the nature of the location and path of the acequia. The contractors-San Antonio Road Boring, and Jalco, Inc.-are to be commended for their alertness in noticing and reporting this encounter with a significant part of San Antonio's history. Without the cooperation of these individuals, a forgotten remnant of this important feature would have gone unnoticed and a unique opportunity to investigate this portion of the acequia would have been missed.

Robert J. Hard served as the principal investigator and C. Britt Bousman the co-principal investigator. CAR illustrator Bruce Moses professionally presents to the reader a clear visualization of the buried acequia's architecture. As always, Marcie Renner's editorial expertise has been immensely helpful.

A special thanks goes to Clint McKenzie, city historic preservation staff officer, who immediately recognized the importance of this opportunity and rendered valuable assistance in the fieldwork. 


\section{Introduction}

In May 1996, the San Antonio River Authority (SARA) contracted with the Center for Archaeological Research (CAR) of The University of Texas at San Antonio to conduct an archaeological assessment of the Alazán Acequia (41BX620). The acequia was discovered just northwest of an area of San Antonio known as Five Points, where five streets intersect: Fredericksburg, North Flores, Fred, Laredo, and West Laurel (Figure 1). More specifically, the channel was found two blocks northwest of Five Points, underneath the Union Pacific rightof-way as it crosses the intersection of Cornell Street and Fredericksburg Road. SARA was conducting a trenching and tunneling operation underneath Fredericksburg Road when the Alazán Acequia was encountered at 7-14 ft below the roadway. Previous investigation of the route of the acequia had revealed that it existed in the area, but its precise route, depth below the modern surface, and architectural construction was unknown until now.

Construction crews broke through the stone-lined acequia tunnel and immediately halted operations while SARA officials notified the city historic preservation office and CAR. Staff archaeologists I. Waynne Cox and David L. Nickels arrived at the site and, with the assistance of city historic preservation staff officer Clint McKenzie and SARA computer automated design (CAD) expert William (Joe) Shannon, were able to fully document the location and architecture of the acequia. The unique tunnel structure is not seen elsewhere on any of the five main acequias in the city. No artifacts were found inside or around the acequia tunnel. Field notes, maps, and photographs are curated at the CAR laboratory.

\section{History of the Alazán Acequia}

The Alazán Acequia was initially conceived as a flood-prevention measure in the aftermath of the costly flood of March 1865. The select committee, appointed by city council to consider preventive measures, submitted several sweeping changes to alleviate what they perceived to be the major cause of the uncontrollable rampage of flood waters following sudden cloudbursts in the San Antonio River basin. The committee concluded that the overflows of the river were caused principally by the massive amounts of water flowing from that collected within the Olmos Creek basin, some five miles north of the city. They recommended that the city engineer be directed to consider the construction of a canal above the city to divert these waters (City Council Minutes [CCM], Office of the City Clerk, City Hall, San Antonio, Texas, C:475). Two years later, engineer F. Giraud surveyed the "land between the northeast branch of the Alazán [Creek] and the Olmos" in light of the practicality of opening a channel to divert their flow below the city (CCM, C:577, 583). The survey resulted in a plan for the construction of such a diversion, but no action was taken; this inaction was due, no doubt, to the complexity and cost of such an endeavor. As a stopgap measure, some clearing of obstructions in the river was accomplished.

The issue, however, was not entirely forgotten. In 1872 the council directed engineer Hartnett to address the remaining dangers of flooding of the river. The concept of diverting water in the Olmos basin was expanded to allow irrigation for the growing west side of the city. The ditch would emanate from a new dam to be constructed above the confluence of Olmos Creek, and it would convey water across the old hard rock quarries in a channel roughly parallel to the old Upper Labor Acequia. It would then pass over the springs at San Pedro Park to beyond Fredericksburg Road, then turn southward to discharge into the Alazán Creek on the far west side of the city. The expenditures for the large dam and three new bridges were unacceptable, and the proposal received strong opposition from the local press (San Antonio Herald, 1 February 1872). However, other factions reconsidered the proposed $\$ 24,000$ as reasonable, since the six-mile ditch would also bring 6,000 acres under irrigation (San Antonio Express [SAE], 2 February 1872). 
In April 1874, a resolution was passed by council calling for ditch construction bids according to the plans submitted by engineer Hartnett (CCM, D:106-107). However, an inspection of the proposed ditch route by the new city engineer, F. Freisleben, was unfavorable. He found several grade and design problems that made the construction impractical as submitted. This delayed the opening of bids until a new route could be surveyed and approved. The new plan called for the channel to utilize the existing Upper Labor ditch to transport the increased flow to San Pedro Avenue, at which point the new ditch would be diverted over San Pedro Springs and then down the western side to flow into Alazán Creek near its confluence with San Pedro Creek (CCM, D:118). This design was selected for bids, and apparently construction was begun in August 1874 (CCM, D:121, 123).

The initial bid for the beginning of construction was $\$ 3,000$. In February 1874 , a second contract to excavate an additional 8,500 cubic yards of earth was accepted for $\$ 1,722.67$, which included stone lining for the acequia (CCM, $\mathrm{D}: 147,153)$. Problems with the construction of the ditch arose almost immediately. In April 1875 , the local newspaper commented, "Mr. Freisleben has discovered that water will not run up hill in the new ditch around San Pedro Springs" (SAE, 16 April 1875). The reports of poor workmanship prompted the council to charge the Committee on Public Improvements to undertake a thorough inspection of the ditch. Their report indicated several major problems with the quality of the work being performed, resulting in a censure of the city engineer ( $S A E$, 5 May 1875). From the nature of the reported findings, this section of the ditch construction entailed the raising of the original Upper Labor ditch walls to contain the increased flow as a result of the addition of the Olmos Creek waters. Despite the various problems encountered, the Alazán Acequia was functioning prior to December 1875 (CCM, D:214).

Problems with the Alazán ditch continued to plague the city. In November 1876 , the new city engineer, Louis Giraud, presented a plan to correct the problems. On the basis of his report, a contract was issued to William Jenkins for $\$ 2,000$ to effect the modifications. Assisted by Jake Marshall and a crew of about 60 workers, the ditch was deepened, "primarily in the area of Fredericksburg and Bandera Roads, which allowed it to flow properly" ( $S A E, 1$ November 1876). The street referred to as "Bandera" is presently Woodlawn Avenue, which means the corrective construction would have been that section north of Fredericksburg Road where the ditch turned south from San Pedro Park. The newspaper reported on the work:

Mr. Wm Jenkins, the contractor, was just twenty-five days on the work of deepening it, and we must give him credit for having done a good job. The water was turned on about noon of Tuesday, and by $10 \mathrm{o}$ 'clock Tuesday night had reached the end, three and threequarters of a mile. The average depth of the water was seventeen inches, the width of the ditch six feet-making $81 / 2$ cubic feet of water flowing through it [SAE, 23 November 1876].

By the turn of the century, the old ditches in the metropolitan area had outlived their purpose and usefulness. As the flow of the water diminished, they became stagnate and soon constituted a health hazard. One by one the old waterways were closed and filled. In 1903 street commissioner Stevens reported that he had filled a portion of the old Alazán ditch near Fredericksburg Road (SAE, 23 September 1903). The Alazan was terminated at the point where it departed from the Upper Labor at San Pedro Avenue and closed, while the older Upper Labor ditch continued to render service until after 1914 (Map, Stormwater Drainage, San Antonio, Texas. June 18, 1914, Historic Preservation Office, Main Plaza Building, San Antonio, Texas). 


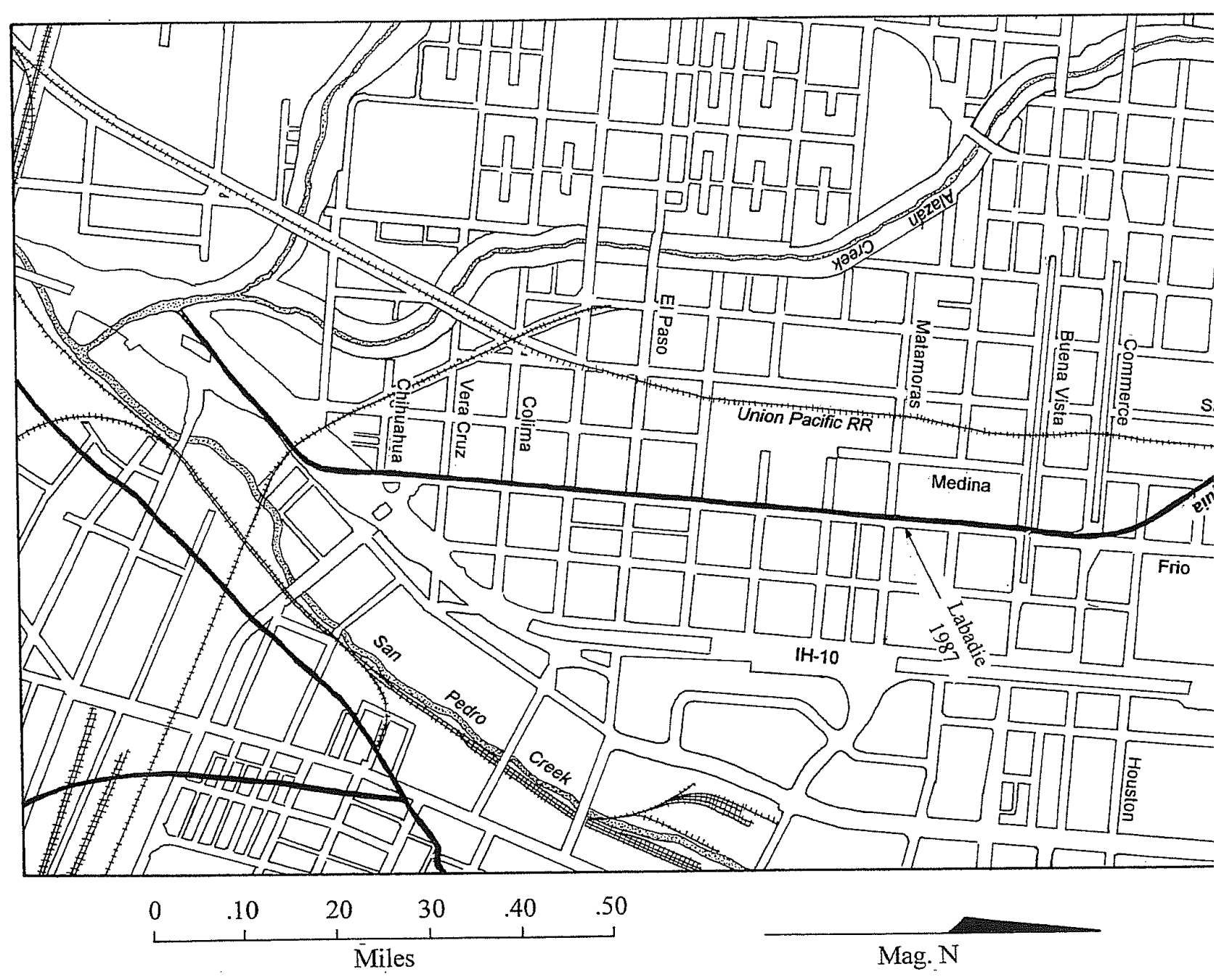

Figure 1. Route of the Alazan Acequia and areas of archaeological investigations. 


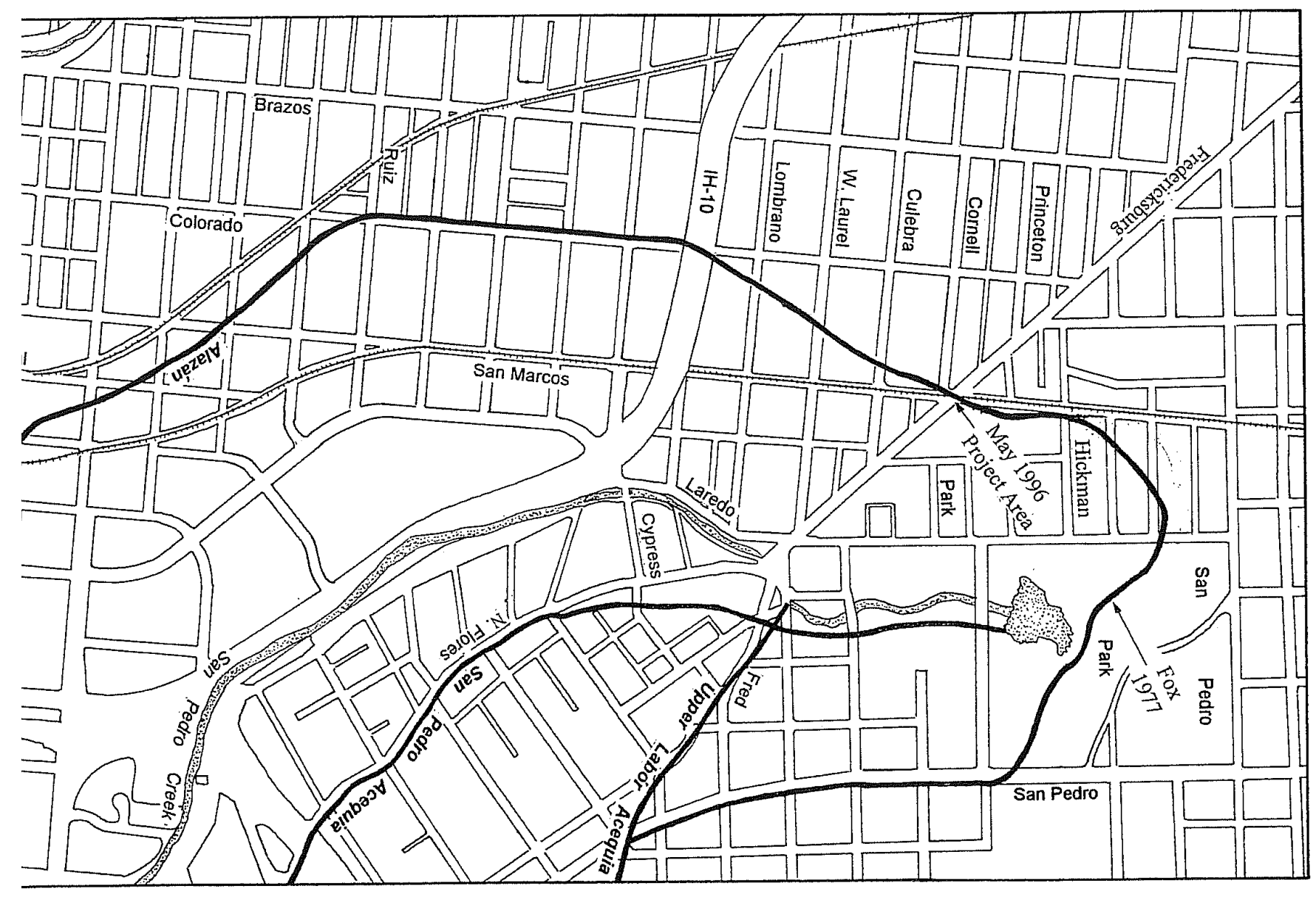




\section{Previous Archaeological Investigations}

The Alazán Acequia is the least documented of the five main acequia channels (Alamo, Alazán, Espada, San Pedro, and San Juan) in San Antonio. This is not by choice but rather because the 4.4-mile-long irrigation channel has not been encountered often during recent construction. While modern city development has occurred over the channel, its considerable depth below the surface-as evidenced by this project-has not only protected it from being disturbed, but has also precluded archaeologists from examining it.

In 1977 CAR staff archaeologist Anne Fox excavated a small portion of the Alazán where it rounded the north side of San Pedro Springs (Fox 1978:11-12), approximately one-third of a mile upstream from the Five Points area (Figure 1). There the ditch was stone-lined, open at the top, and had no cap. Fox noted that courses or layers of more finely quarried limestone blocks had been added to the top of the original walls, evidently a later construction event, and the south wall contained a coating of cement which covered both construction phases. At the time she questioned whether the added courses of stone and cement lining were part of Giraud's attempt to fix the problems of the initial design and poor construction.

The Alazán Acequia was again "rediscovered" and documented in 1987 (Labadie 1987:12, 30) on the southern edge of New City Block (NCB) 266, on the west edge of S. Frio Street (Figure 1), some 1.4 miles downstream from the Five Points area. There the ditch was also stone-lined, with no cap, and no smooth cement lining.

\section{The Current Project}

In May 1996, a SARA construction crew was boring a sewer tunnel at the intersection of Cornell Street and Fredericksburg Road. While digging, the construction crews encountered a limestone casing of the Alazán Acequia, and immediately halted operations while SARA officials notified the city historic preservation officer and CAR.

Archaeologists gained access to the SARA tunnel by climbing down an extension ladder and walking through $60 \mathrm{ft}$ of newly joined concrete sewer pipes, up to the point where the Alazán Acequia was encountered. The field crew was equipped with hard hats, rubber boots, flashlights, and all equipment needed to photograph, measure, and map the acequia. SARA tunneling activities had broken through the stone acequia at a transverse angle (Figure 2), making an irregular 40-inch-high by 44-inch-wide opening in its south wall (Figure 3).

The acequia was a near perfectly round casing measuring 48 inches in diameter on the interior and constructed of hand-hewn limestone bonded together with a sandy paste mortar. The handquarried stones were all keystone shaped, with 10-inch faces to the tunnel's interior. Each stone was 36 inches long by 18 inches thick. A smooth coating of roman cement, three-quarters inch thick, was applied to the interior of the tunnel up to within 8 inches of the keystone ceiling.

Sediments outside of the acequia were mottled, which is probably due to backfill from the construction of the channel. The interior of the acequia was filled with silt to within 6 to 7 inches of the ceiling (Figure 4). Photographs and measurements were later used to construct an artistic rendition of the architecture (Figure 5).

Archaeologists were able to shine flashlights into the opening between the ceiling and the silt deposits and at a distance of about $25 \mathrm{ft}$ observed a slight curvature in the tunnel's route to the southwest. To the northeast flashlights allowed the field crew to see that the tunnel extended for at least $40 \mathrm{ft}$, but the light was not powerful enough to reach beyond that. No artifacts were observed during the investigation. 


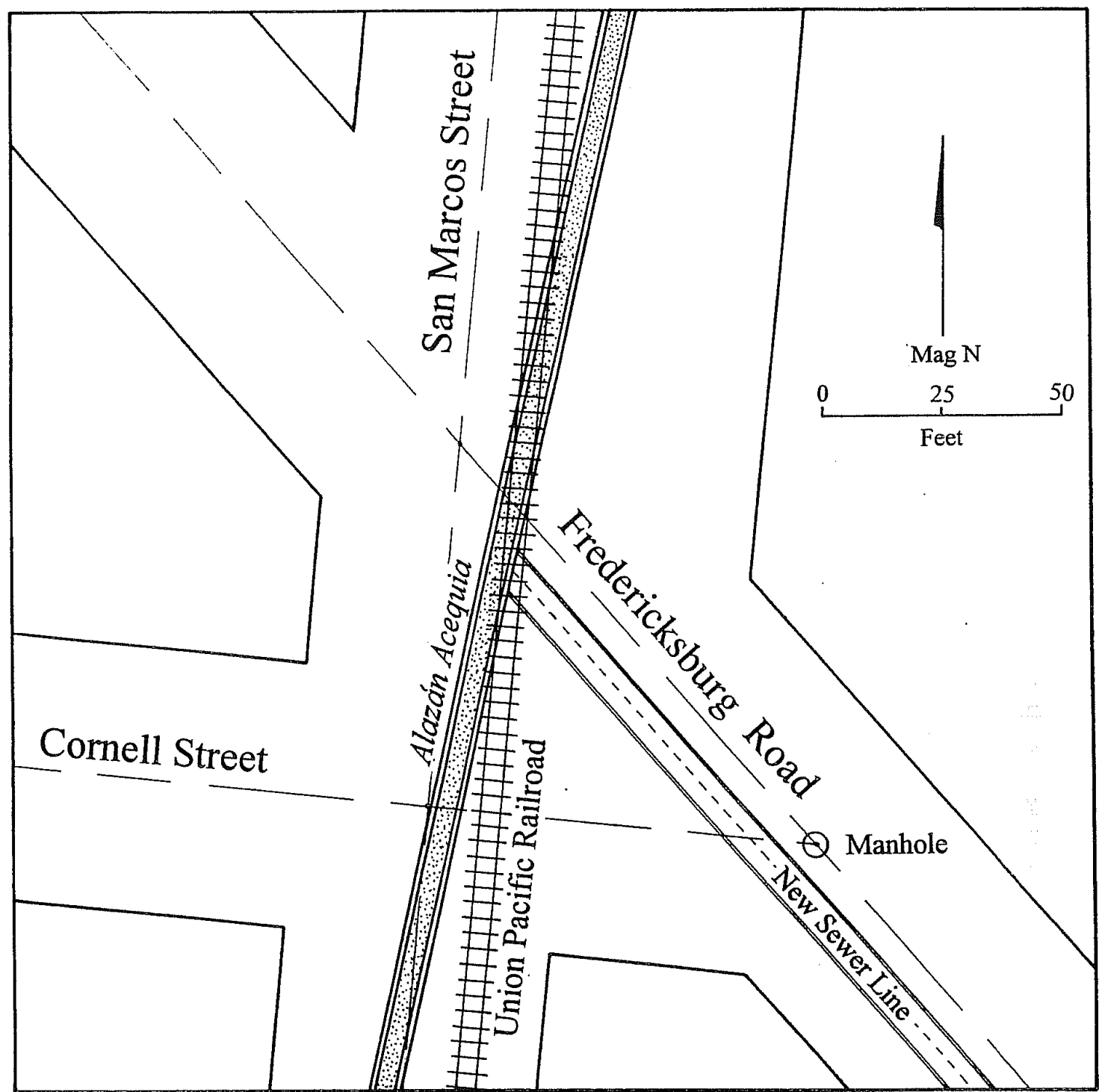

Figure 2. Map of the project area.

\section{Discussion and Conclusions}

In some ways the late-nineteenth-century engineering and architectural techniques used to initially construct the Alazán Acequia were less adequate than those used by the Spanish some 150 years earlier. However the redesign and subsequent reconstruction of the acequia in 1876 is an excellent example of engineering and masonry architecture. No mention of a limestone-lined pipeline of this magnitude for any of the city's acequias has been found in the archival records, so this section represents a unique portion of San Antonio's acequia system.

With such a massive pipeline of stone buried underground, cleaning it out would have been next to impossible. Certainly the engineers didn't want the tunnel becoming obstructed with trash and debris carried in by rushing storm waters. The smoothed cemented interior eliminated any edges or angles on the hand-quarried stones, thus 
allowing debris to pass through unobstructed. The same cement coating was used on the acequia upstream near San Pedro Springs, although there the channel was neither capped nor constructed as a circular pipeline Fox (1978).

This discovery raises many additional questions. Just how far does this hand-dressed pipeline run before emerging above ground at both ends? Strong indications are found that the underground portion began at Hickman Street, just to the east of the intersection with the railroad where a storm drain is presently located. While archaeologists documented the acequia, a small yet constant seepage of water was observed near the bottom. SARA engineers traced the water source to the storm drain on Hickman Street.
Another question that arises is, What is the exact route of the remainder of the acequia tunnel? One suggestion is that a buried pipeline would be appropriate in areas where higher surface contours prohibit flow in an open channel. The buried pipeline was the only way to ensure water was still flowing downhill even though the acequia's route crossed through higher surface contours west of San Pedro Park. A city engineering map drawn in 1914 by S. M. Gray (Stormwater Drainage, San Antonio, Texas, June 18, 1914, on file at the Historic Preservation Office, Main Plaza Building, San Antonio, Texas) was compared to a modern topographic map (USGS 1973). The comparison revealed that no significant variations in elevation have occurred since then. There is no record of major flooding or development occurring in the project

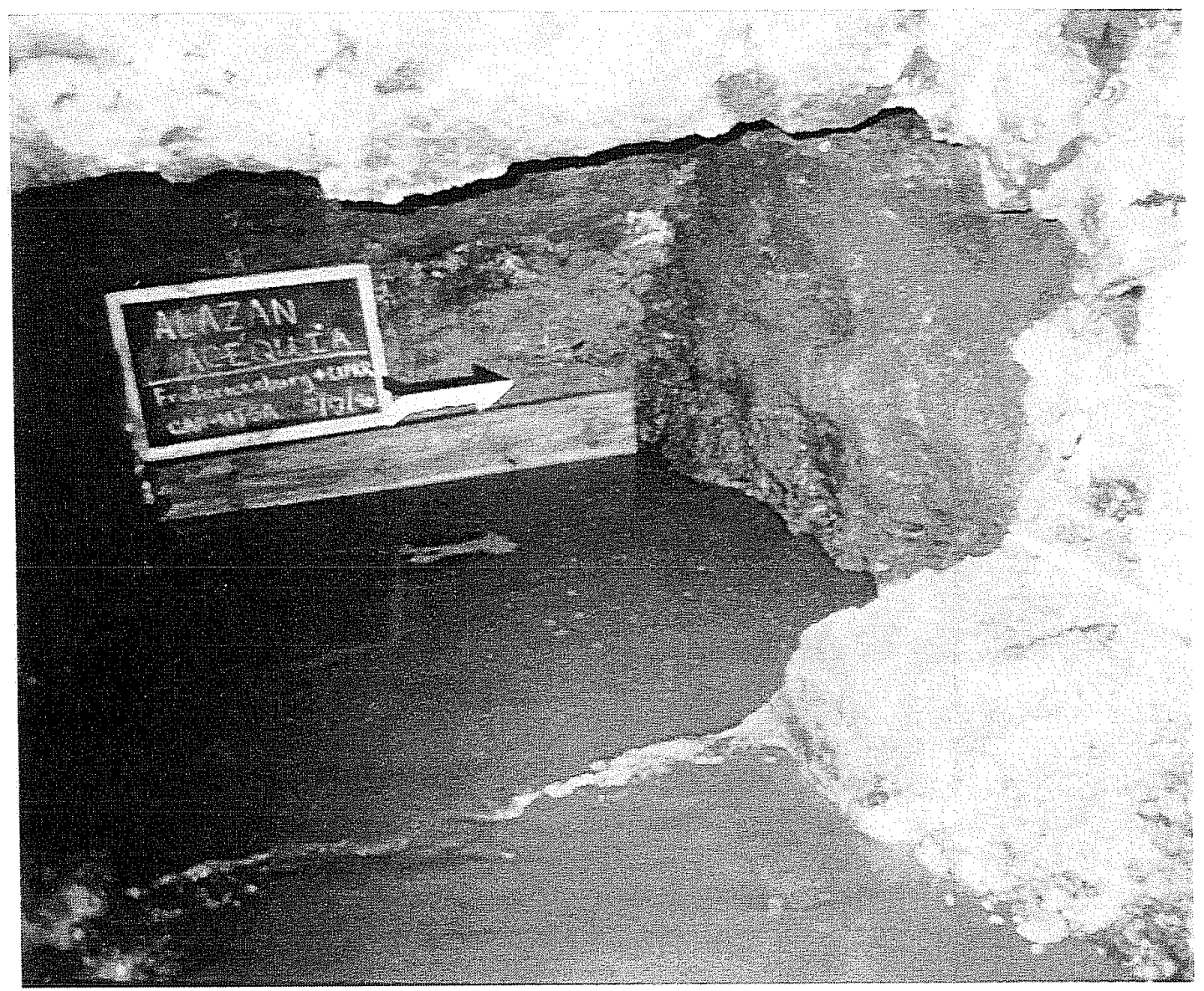

Figure 3. SARA construction crews encountered the Alazan Acequia from the east side. 


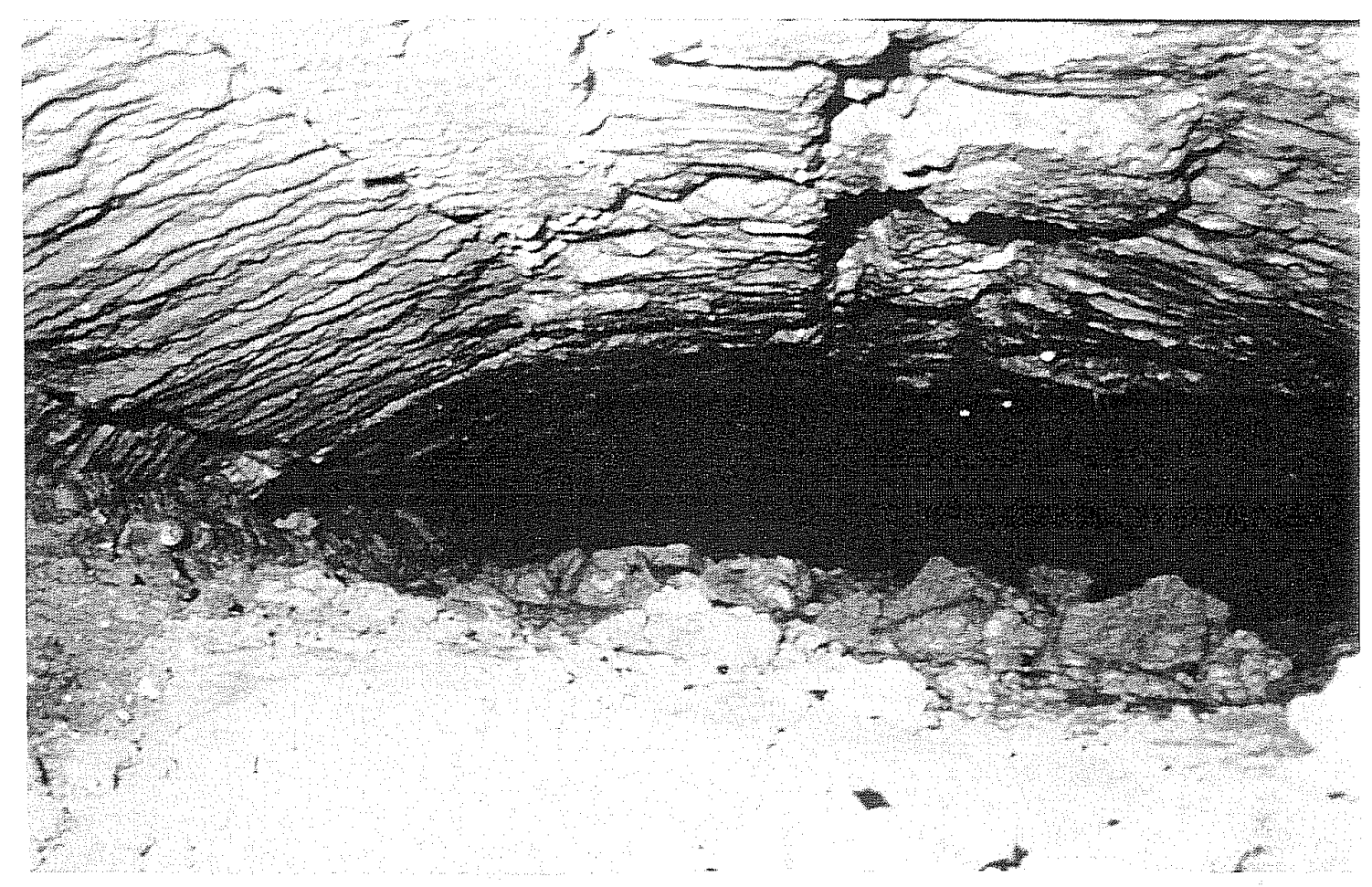

Figure 4. Interior of the Alazan Acequia tunnel.

area between 1875 and 1914 to support any significant terrain alteration.

Fox (1978) documented the open acequia channel in San Pedro Park at approximately $670 \mathrm{ft}$ above mean sea level (amsl). The acequia tunnel documented by this report was found seven feet below a point on the modern surface, which is approximately $675 \mathrm{ft}$ amsl. However, approximately two feet of fill has been added over the area in modern times, as observed in an adjacent manhole (Figure 2), which places the 1875 surface at approximately $673 \mathrm{ft}$ amsl. Thus the tunnel was five feet below the 1875 surface at $668 \mathrm{ft}$ AMSL, and two feet below the San Pedro Springs elevation.

Given city engineer Freisleben's 1875 discovery "that water will not run up hill" in the Alazán Acequia, we should expect to find the pipeline as it enters terrain where the surface is greater than the $670 \mathrm{ft}$ amsl at San Pedro Springs; that would be near the intersection of the Union Pacific RR and Hickman Street on the west of San Pedro Park. At this point, it was apparently necessary to bury the acequia conduit deeper to maintain flow for the ditch. This probably resulted in the contract issued to William Jenkins in November 1876. The tunnel should end near the intersection of Colorado and Lombrano streets, near Interstate 10 (Figure 6), where the surface terrain once again falls below $670 \mathrm{ft}$ amsl.

The Alazán Acequia is the only one documented in San Antonio thus far that has a buried tunnel conduit. Although the archival information on the town's old ditches has been studied in-depth, references to a tunneled water channel have not been found. This project afforded a unique opportunity to document historic construction of the 1870 s tunnel. 


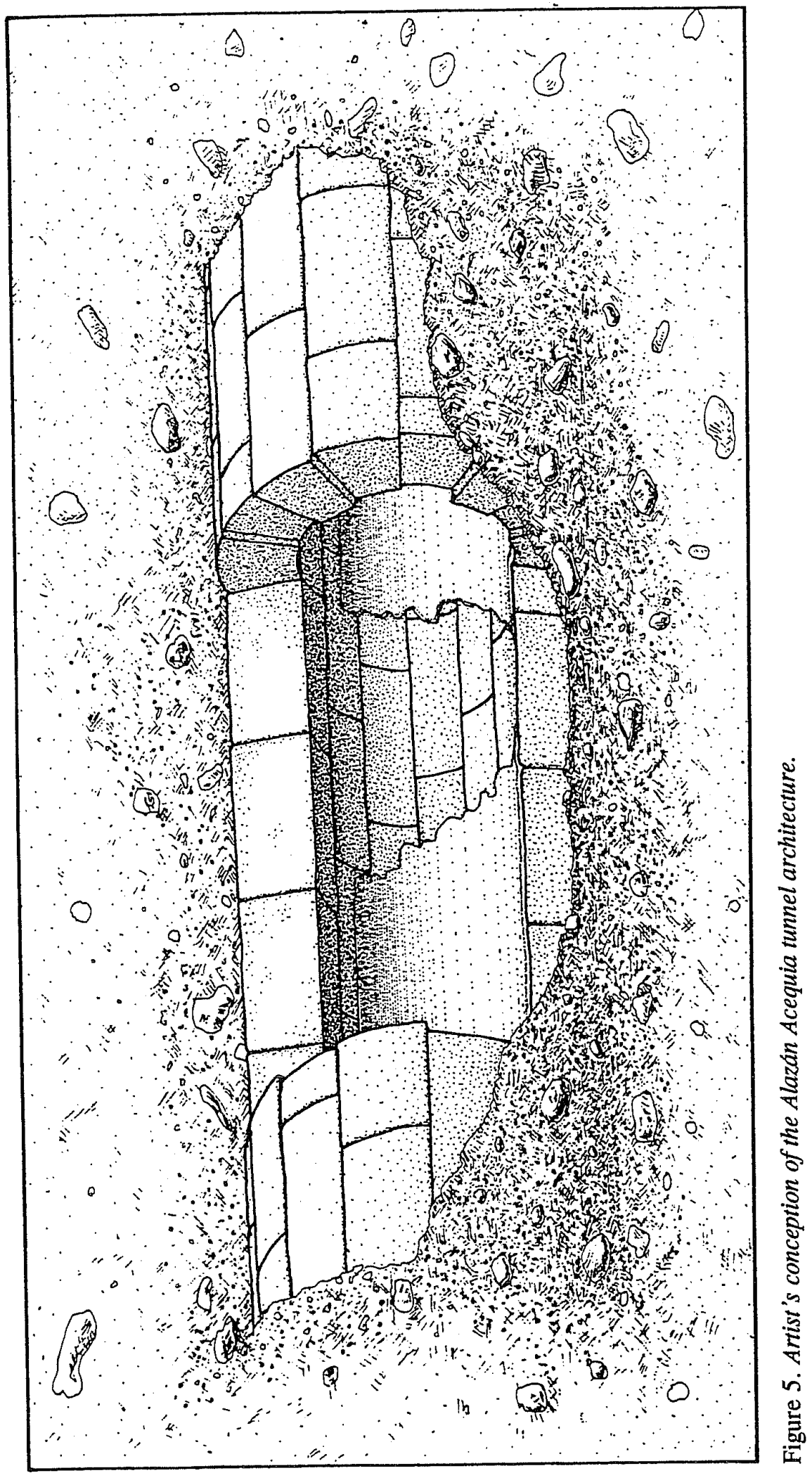




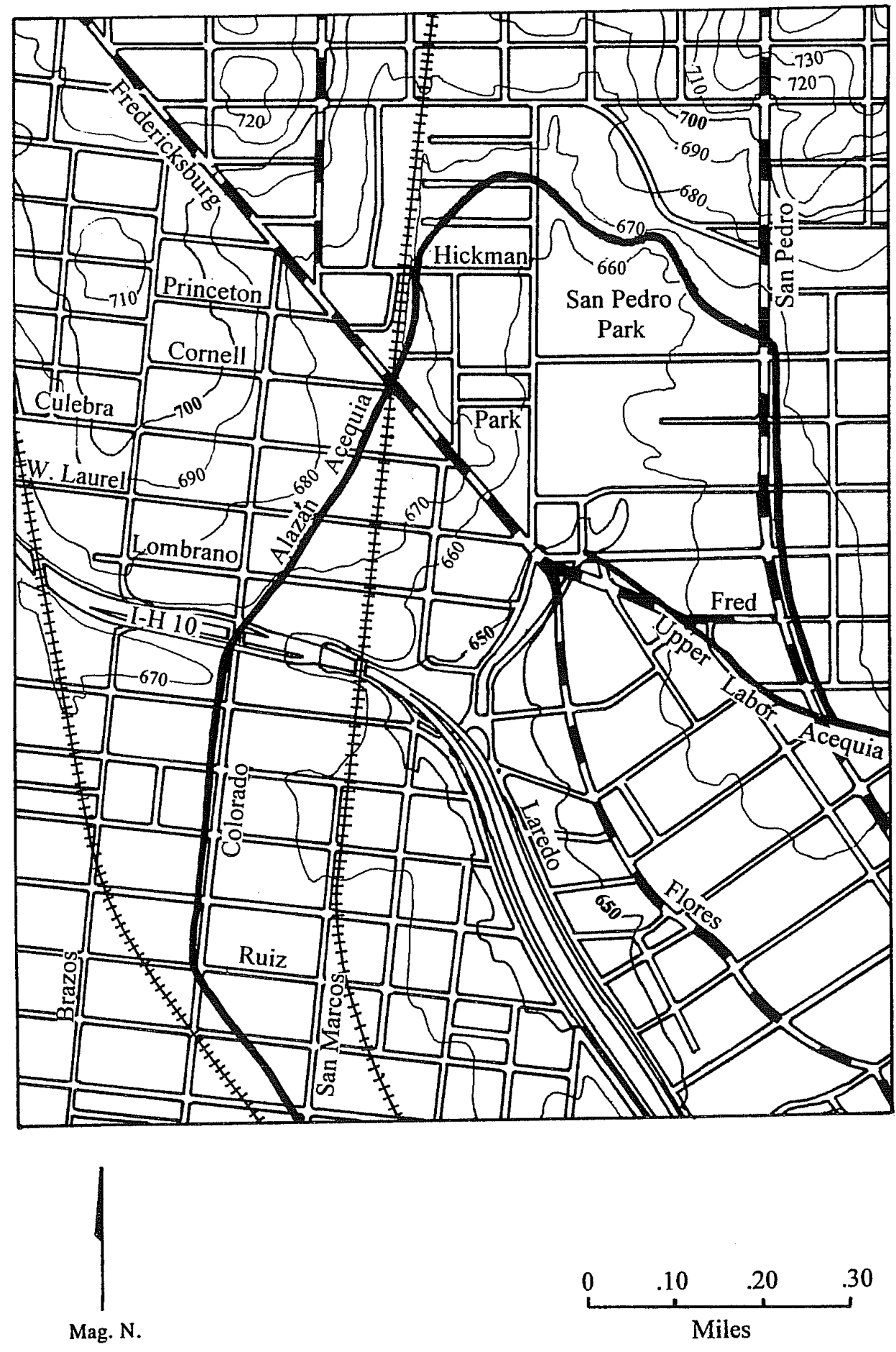

Figure 6. Topographic map of the project area. 


\section{References Cited}

Fox, A. A.

1978 Archaeological Investigations of Portions of the San Pedro and Alazan Acequias in San Antonio, Texas. Archaeological Survey Report, No. 49. Center for Archaeological Research, The University of Texas at San Antonio.

Labadie, J. H.

1987 An Archaeological and Historical Assessment of the Vista Verde South Project, San Antonio, Texas. Archaeological Survey Report, No. 156. Center for Archaeological Research, The University of Texas at San Antonio.

San Antonio Herald (San Antonio, Texas)

1872 Local Comments. 1 February.

San Antonio Express [SAE] (San Antonio, Texas)

1872 Local Affairs. 2 February.

1875 Local Affairs. 16 April.

1875 Report of the Public Improvements Committee Upon the Upper Labor Ditch Contract Work. 5 May.

1876 The Alazan Ditch. 1 November.

1876 The Alazan Ditch. 23 November.

1903 City Hall Notes. 23 September. 